\title{
Method of Selecting Energy-Efficient Parameters of an Electric Asynchronous Traction Motor for Diesel Shunting Locomotives-Case Study on the Example of a Locomotive Series ChME3 (ЧMЭ3, ČME3, ČKD S200)
}

\author{
Valeriy Kuznetsov $^{1}$ (D), Ewa Kardas-Cinal ${ }^{2}{ }^{(D}$, Piotr Gołębiowski $^{2, *} \mathbb{D}$, Borys Liubarskyi ${ }^{3}$, \\ Magomedemin Gasanov $^{3}$, Ievgen Riabov ${ }^{3}{ }^{\mathbb{D}}$, Lilia Kondratieva ${ }^{4}$ and Michał Opala ${ }^{2} \mathbb{D}$ \\ 1 Railway Research Institute, 04275 Warsaw, Poland; vkuznetsov@ikolej.pl \\ 2 Faculty of Transport, Warsaw University of Technology, 00662 Warsaw, Poland; \\ ewa.kardascinal@pw.edu.pl (E.K.-C.); michal.opala@pw.edu.pl (M.O.) \\ 3 National Technical University "Kharkiv Polytechnic Institute", 61002 Kharkiv, Ukraine; \\ lboris1911@ukr.net (B.L.); kh.kajvika@gmail.com (M.G.); riabov.ievgen@gmail.com (I.R.) \\ 4 LLC “Mykolaiv Locomotive Repair Plant”, 54000 Mykolaiv, Ukraine; kondratieva.lilia@gmail.com \\ * Correspondence: piotr.golebiowski@pw.edu.pl
}

check for updates

Citation: Kuznetsov, V.; Kardas-Cinal, E.; Gołẹbiowski, P.; Liubarskyi, B.; Gasanov, M.; Riabov, I.; Kondratieva, L.; Opala, M. Method of Selecting Energy-Efficient

Parameters of an Electric Asynchronous Traction Motor for Diesel Shunting Locomotives-Case Study on the Example of a Locomotive Series ChME3 ( ЧMЭ3, ČME3, ČKD S200). Energies 2022, 15, 317. https://doi.org/10.3390/ en15010317

Academic Editor: Mario Marchesoni

Received: 21 November 2021

Accepted: 22 December 2021

Published: 3 January 2022

Publisher's Note: MDPI stays neutral with regard to jurisdictional claims in published maps and institutional affiliations.

Copyright: (C) 2022 by the authors. Licensee MDPI, Basel, Switzerland. This article is an open access article distributed under the terms and conditions of the Creative Commons Attribution (CC BY) license (https:// creativecommons.org/licenses/by/ $4.0 /)$.

\begin{abstract}
One of the assumptions made during the modernization process of diesel shunting locomotives is the replacement of a diesel traction motor with a DC generator with an electric asynchronous traction motor. The article aimed to develop a method of selecting energy-efficient parameters of an asynchronous electric traction motor for diesel shunting locomotives, which will ensure that its operating energy efficiency will be as high as possible. The method was verified on the example of a locomotive series ChME3 (ЧMЭ3, С̌ME3, С̌KD S200). It has been found that using a traction asynchronous electric drive on a ChME3 locomotive, its efficiency increases in comparison with DC electric motors by $3-5 \%$ under the long-term operation modes and by $7-10 \%$ during locomotive operation with traction at the adhesion limit. Using a new traction gearbox with a higher gear ratio expands the speed range in which the asynchronous traction drive operates with a high-efficiency factor. It is effective to use a traction asynchronous electric drive to modernize ChME3 diesel locomotives in case of their use under the modes requiring the implementation of maximum traction forces at low speeds. A further increase in the efficiency of the traction asynchronous electric drive is possible based on the optimal design of the wheel-motor unit and the asynchronous traction electric drive.
\end{abstract}

Keywords: diesel shunting locomotives; parameters of an asynchronous traction motor; locomotive series ChME3; traction characteristics; the influence of gear ratio on locomotive power index

\section{Introduction}

Efficient transportation aims to meet the demand for transport services while minimizing resources used for this purpose and reducing cost. Improvement of transport efficiency is possible, on the one hand, by using the resources already held, by using tools for planning [1], organization [2-4], and optimization of the involved processes [5-7]. On the other hand, it is possible to further increase transportation efficiency by developing appropriate technology that enables converting the available forms of energy into the vehicles' mechanical energy, assuming the minimization of energy losses. Technologies of this type can cover a wide range of applications, examples being technologies used in the wheel-rail interaction zone [8,9] or technologies used to control and propel the vehicle [10-12]. In railway transport, a significant part of the cost is constituted by various technical and shunting operations, which constitute an integral part of transportation [13]. Considering the high wear degree of traction vehicles used in Ukrainian enterprises and JSC "Ukrzaliznytsia" shunting operations, it is expedient to radically renew the stock of 
shunting locomotives. The inconsistency of their technical characteristics and parameters referring to the standards of up-to-date locomotives should also be considered. Modernization is the most widely spread approach, currently performed in two ways: profound modernization of a locomotive or its motorization. The crucial factor of both methods is replacing a diesel engine, which significantly reduces fuel costs [12,14-16].

One of the assumptions made during the modernization process of diesel shunting locomotives, which allows to reduce energy consumption and reduce the negative impact of railway transport on the environment, is the replacement of a diesel traction motor with a DC generator with an electric asynchronous traction motor. The problem with this assumption is how to select the parameters of the asynchronous motor to maintain the locomotive's appropriate traction parameters and ensure that its operating energy efficiency is as high as possible. Therefore, the aim of the article is to develop a method of selecting energy-efficient parameters of an asynchronous electric traction motor for a diesel shunting locomotive. The method will be verified using the example of a ChME3 (ЧMЭ3, ČME3, ČKD S200) series locomotive.

The developed method is divided into three stages. The first stage of forming a method of selecting energy-efficient parameters of an asynchronous electric traction motor for diesel shunting locomotives is developing a proprietary way of creating the traction characteristics of a vehicle equipped with a DC electric traction motor. We will carry out a velocity range of $1-60 \mathrm{~km} / \mathrm{h}$. The current of the electric traction motor has been determined for each velocity value when the traction power is achieved during the start, or the power is input to electric motors. The initial value of current was assumed in our calculations as $100 \mathrm{~A}$ raised with a step of $5 \mathrm{~A}$. It was also believed that electric motors function without field weakening at velocities less than $15 \mathrm{~km} / \mathrm{h}$. In comparison, at velocities of $15-30 \mathrm{~km} / \mathrm{h}$, electric motors operate with a field weakening by $35 \%$. Moreover, at speeds of higher than $30 \mathrm{~km} / \mathrm{h}$ with a field weakening by $20 \%$. In the final stage, the energy efficiency of the motor is assessed.

The second stage is developing a proprietary method of developing the traction characteristics of a vehicle equipped with an asynchronous electric traction motor. The rotor current frequency where initial tractive force is achieved for each velocity value or the power supplied to electric motors has been defined. The initial value of the rotor current frequency has been assumed as $0.01 \mathrm{~Hz}$ and rises in increments of $0.01 \mathrm{~Hz}$. The dependence of voltage on the frequency is considered proportional ( $U / f=$ const) until the voltage becomes equal to the maximum voltage of the motor. The motor operates with the rated flux coupling in the range where the power is supplied according to $\mathrm{U} / \mathrm{f}=$ const. It is assumed that the voltage of the intermediate circuit of the traction converter for all operation modes of the motor is $600 \mathrm{~V}$. It has been assumed that the losses in the traction converter are proportional to the phase current. Power losses in the electric motor from maximum harmonic voltages and currents are estimated as $0.5 \%$ of the supplied power for all operating modes. In the final stage, the energy efficiency of the motor is assessed. The third stage of developing the method of selecting energy-efficient parameters of an electric asynchronous traction motor for diesel shunting locomotives will be based on the study of the influence of the traction gear ratio on the locomotive power index. As an indicator for assessing the quality of the solution (objective function), the efficiency value of the asynchronous motor was adopted, which can be installed in the vehicle, at a specific driver's controller position, for a specific speed, at different values of traction gear ratios.

The contribution of this article to the scientific area is that the authors propose a selection procedure for the value of the gear ratio of the traction gear when using an electric drive based on asynchronous motors (for shunting locomotives) based on an assessment of energy efficiency. Moreover, the dependence of the energy efficiency of shunting locomotives on the parameters of individual components of an electric traction drive was investigated.

To achieve the article's goal, it has been divided into five sections. Section 1 introduces the problem of the modernization of diesel shunting locomotives. Section 2 discusses the 
solutions used in the modernized locomotives owned by JSC Ukrzaliznytsia (the national railway undertaking and infrastructure manager in Ukraine). Section 3 describes the method of selecting energy-efficient parameters of an electric asynchronous traction motor for diesel shunting locomotives, while Section 4 describes its verification on accurate data. Section 5 contains a discussion of the results and a summary of the research carried out.

\section{Problem Review}

When renovating, replacing the diesel engine or diesel generator is carried out. This type of modernization was applied on ChME3 locomotives (in Ukraine it was an installation of 4D80B diesel type, in the CIS countries it was an installation of 4-36DG diesel type or diesel generator of 1-PD4B type), TEM7 (application of the ABC company diesel engine), TGM4, and TGM6 (application of Cummins and Caterpillar companies diesel engines). At the same time, the remaining locomotive equipment is not replaced or is replaced only in the portion necessary to operate with a new engine (Figure 1).

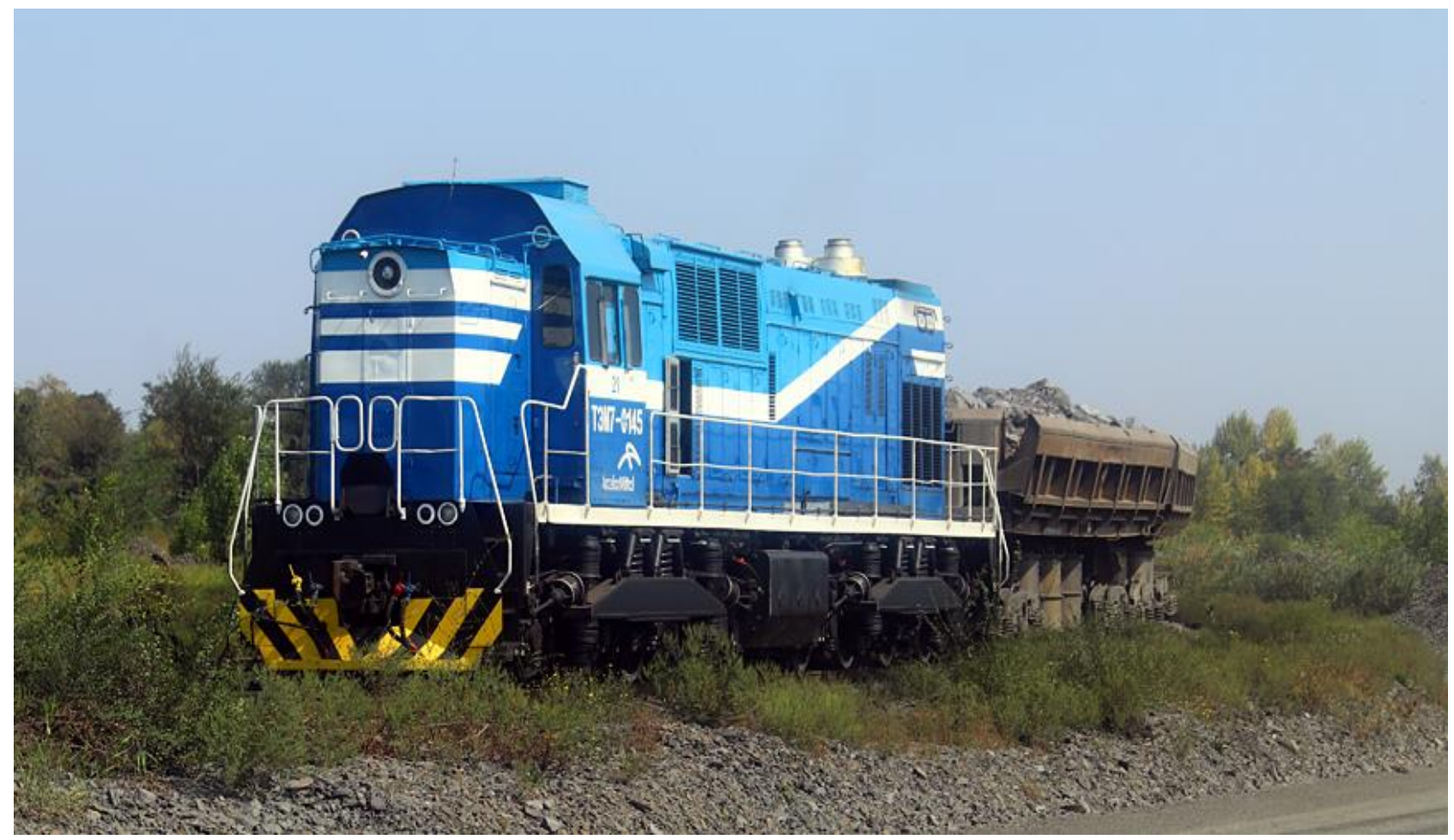

Figure 1. TEM7 locomotive after remotorization at LLC "Mykolaiv locomotive repair plant". Source: own work.

Comprehensive modernization includes the complete replacement of a significant portion of the locomotive's equipment and the modernization of its key components. Profound modernization regarding ChME3 locomotives (modernization projects of CZ LOKO, ZOS Zvolen, JSC VNIKTI enterprises), TEM2 (projects of Mega Techno, General Electric, Poltava TRZ), TGM4, and TGM6 (project of Mega Techno, company, Mykolaiv locomotive repair plant, Vilnius locomotive repair depot) was performed in the CIS countries.

We obtain a locomotive with a new diesel generator, a cooling system, a braking system, a driver's cab, control systems, diagnostics, etc. through this type of modernization. The mainframe of the locomotive and carts are taken from the serial locomotive, which undergoes significant repairs and is completed for mounting new equipment (Figure 2). 


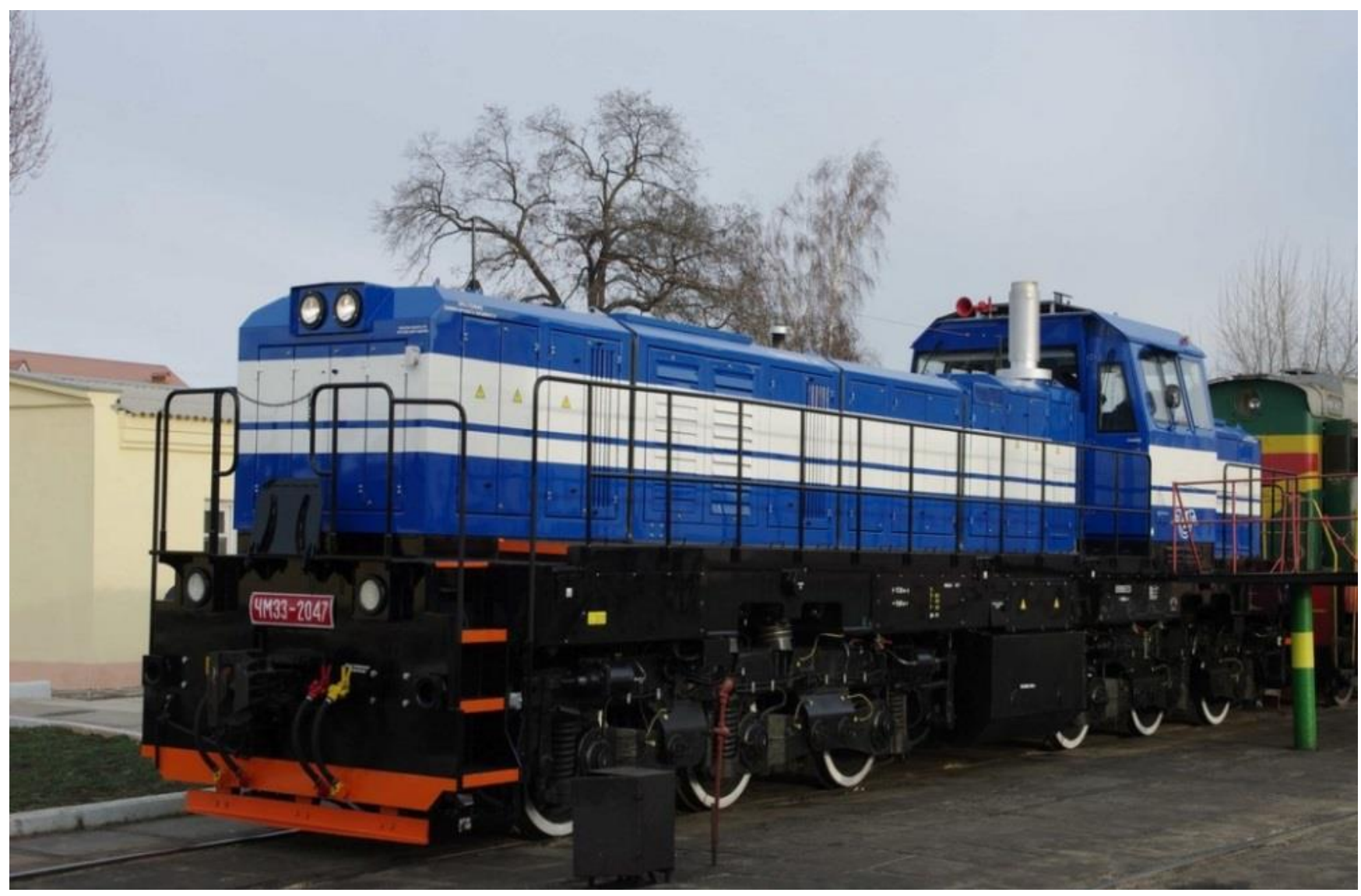

Figure 2. Modernized ChME3 locomotive at the JSC “Ukrzaliznytsia" regional branch of "Odessa Railway". Source: own work.

Under profound modernization of ChME3 shunting locomotives, the transition to an AC/DC electric power drive is effective with the use of serial traction electric DC motors that are subject to significant repair, with insulation materials of the highest thermal resistance class installed as a rule. This allows the long-term current of the electric motor to be increased, increasing the locomotive's long-term traction power by approximately $7-10 \%$. However, losses in the electric motor occur, i.e., the decrease in the locomotive electrical traction drive's energy efficiency.

A further increase of traction power, which is one of the critical indicators of the locomotive, is possible using more advanced traction DC motors or an electric drive based on AC motors [11,17-19]. Further use of DC motors can hardly be called promising, taking into account that the design of DC traction motors has almost exhausted the improvement potential nowadays, and the analysis of technical parameters of DC electric motors from various manufacturers demonstrates their almost similar level (in particular, the efficiency factor of electric motors). On the other hand, electric traction drives based on asynchronous electric motors are used by most leading manufacturers. The implementation of such motors provides high traction power, up to $70-80 \mathrm{kN}$ / axis (axial loading being $250 \mathrm{kN}$ ), and, secondly, a high-efficiency factor of power use is ensured. However, no numerical estimation of the energy efficiency indicators obtained using an asynchronous drive is provided. Therefore, the study of the energy efficiency of a locomotive with asynchronous traction electric drive is relevant. This paper aims to assess the efficiency of electric traction drives based on DC motors and asynchronous motors and determination of the areas of their application on shunting locomotives.

Summing up, in the available literature, it is recommended to calculate the choice of the gear ratio of the traction reducer of the locomotive based on the possibility of increasing the rotational speed. This article proposes a selection process based on energy efficiency. 
The analyzed literature did not consider the energy efficiency indicators for the choice of the gear ratio.

The authors tried to include new publications indexed in the Scopus and Web of Science databases in the list of references. It should be noted that private companies, which are engaged in designing asynchronous electric drives for locomotives in Ukraine, do not publish the details of their solutions. The results of such works are not available to scientists in Ukraine. Therefore, there were problems concerning access to such materials while working on the article. At the same time, the analysis of the literature presented in this article made it possible to formulate a research gap.

\section{The Method of Selecting Energy-Efficient Parameters of an Electric Asynchronous Traction Motor for Diesel Shunting Locomotives}

The first stage of developing a method of selecting energy-efficient parameters of an asynchronous electric traction motor for diesel shunting locomotives is developing a proprietary method of creating the traction characteristics of a vehicle equipped with a DC electric traction motor. The method is presented in Figure 3.

The symbols in Figure 3 have the following interpretation:

- $\quad p$-vehicle's number

- $\quad P$-number of vehicles

- I-minimal current (A)

- $d c p(p)$-driver's controller position in vehicle $p$

- $v(p)$-velocity of vehicle $p(\mathrm{~km} / \mathrm{h})$

- $\quad D C P(p)$-number of driver's controller position in vehicle $p$

- $\quad i(p, d c p(p), v(p))$ - current on motor in vehicle $p$ on driver's controller position $d c p(p)$ and velocity $v(p)(\mathrm{A}), i(p, d c p(p), v(p)) \equiv i$

- $\quad F(p, d c p(p), v(p))$ - traction force in vehicle $p$ on driver's controller position $d c p(p)$ and velocity $v(p)(\mathrm{N})$

- $\quad \eta(p, d c p(p), v(p))$ - energy efficiency of motor in vehicle $p$ on driver's controller position $d c p(p)$ and velocity $v(p)(\%)$

We will carry out the method for the velocity range of $1-60 \mathrm{~km} / \mathrm{h}$. The current of the electric traction motor has been determined for each velocity value when the traction power is achieved during the start, or the power is input to electric motors. The initial value of current was assumed in our calculations as $100 \mathrm{~A}$ raised with a step of $5 \mathrm{~A}$. It was also assumed that at velocities less than $15 \mathrm{~km} / \mathrm{h}$, electric motors function without field weakening, while at velocities of $15-30 \mathrm{~km} / \mathrm{h}$, electric motors operate with a field weakening by $35 \%$. Moreover, at velocities of higher than $30 \mathrm{~km} / \mathrm{h}$ with a field weakening by $20 \%$. The calculation is based on the technique referred to in [20].

Energy efficiency of motor $\eta(p, d c p(p), v(p))$ is calculated from the Equation (1).

$$
\eta(p, d c p(p), v(p))=\frac{P_{2}(p, d c p(p), v(p))}{P_{1}(p, d c p(p), v(p))} \cdot 100 \%[\%]
$$

where:

- $\quad P_{2}(p, d c p(p), v(p))$-output mechanical power obtained on motor in vehicle $p$ on driver's controller position $d c p(p)$ and velocity $v(p)(\mathrm{kW})$

- $\quad P_{1}(p, d c p(p), v(p))$-active power absorbed by motor in vehicle $p$ on driver's controller position $d c p(p)$ and velocity $v(p)$ in steady state $(\mathrm{kW})$

The second stage of developing a method of selecting energy-efficient parameters of an asynchronous electric traction motor for diesel shunting locomotives is developing a proprietary method of developing the traction characteristics of a vehicle equipped with an asynchronous electric traction motor. The method is presented in Figure 4. 


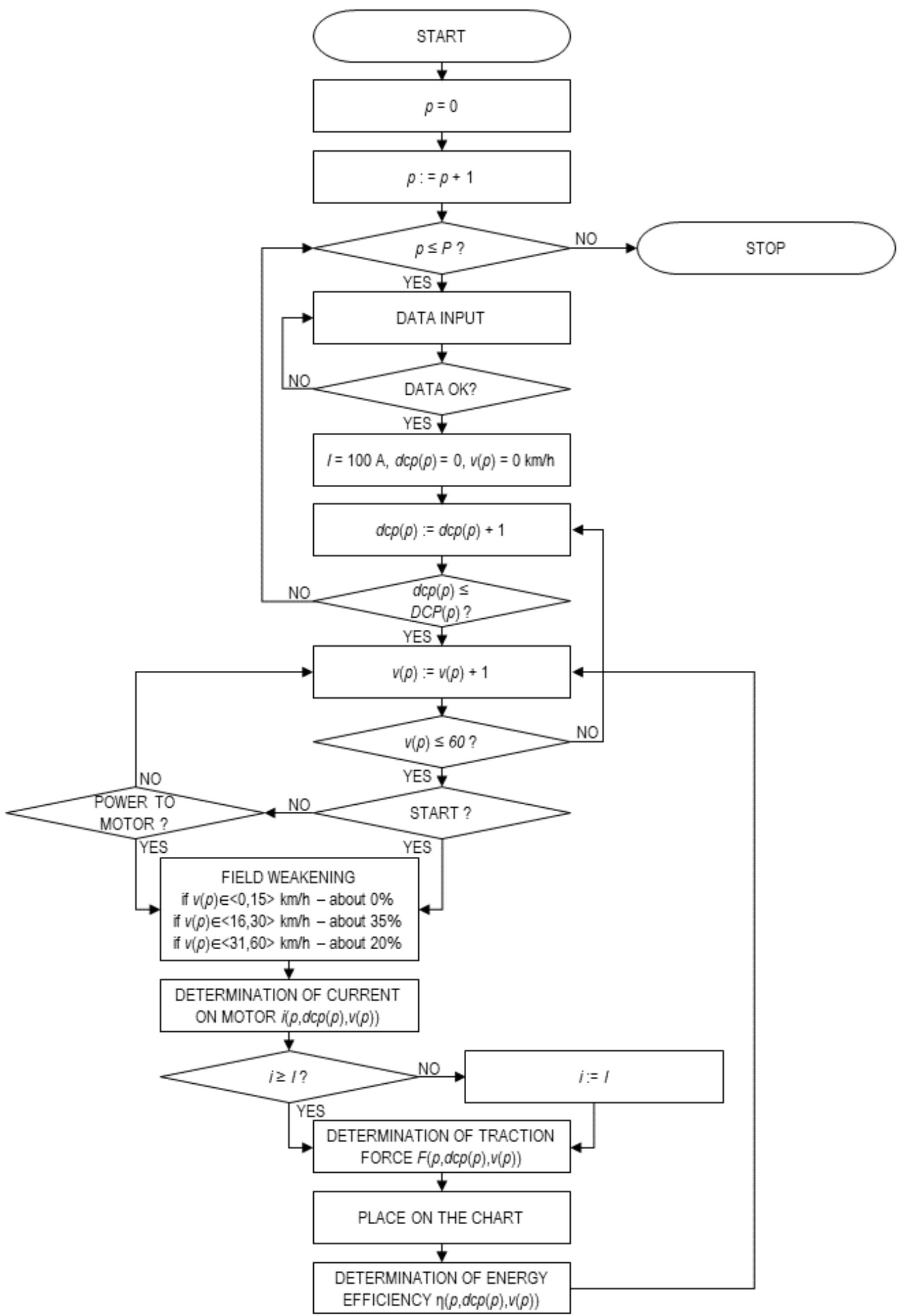

Figure 3. Author's method of developing the traction characteristics of a vehicle equipped with an electric DC traction motor and determining the engine's energy efficiency. Source: own work. 


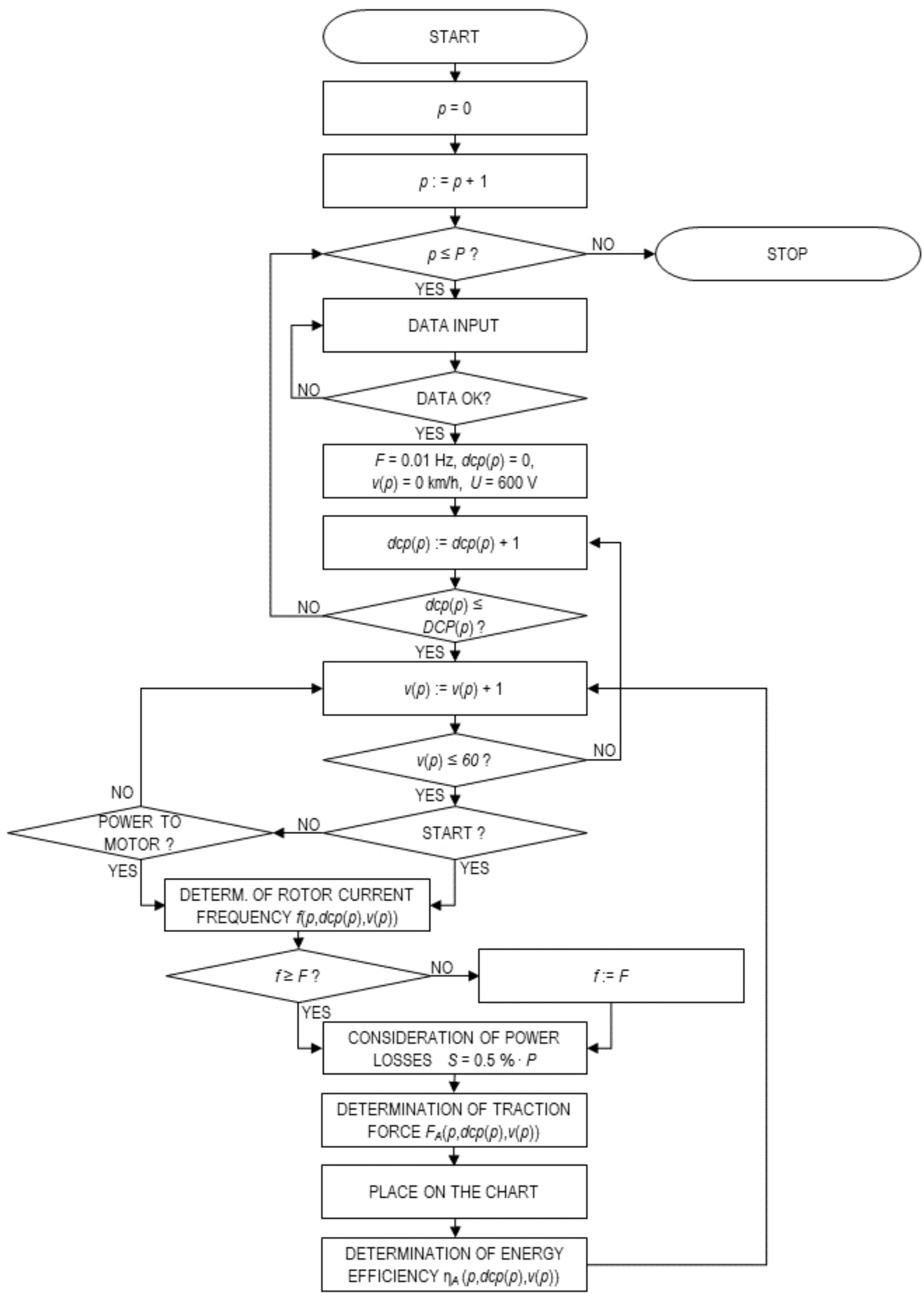

Figure 4. Author's method of developing the traction characteristics of a vehicle equipped with an electric asynchronous traction motor and determining the engine's energy efficiency. Source: own work. 
The symbols in Figure 4 have the following interpretation:

- $\quad F$-minimal rotor current frequency $(\mathrm{Hz})$

- $\quad U$-voltage of the intermediate circuit of the traction converter $(\mathrm{V})$

- $f(p, d c p(p), v(p))$-rotor current frequency on motor in vehicle $p$ on driver's controller position $d c p(p)$ and velocity $v(p)(\mathrm{Hz}), f(p, d c p(p), v(p)) \equiv f$

- $S(p, d c p(p), v(p))$ - power losses in the electric motor in vehicle $p$ on driver's controller position $d c p(p)$ and velocity $v(p)(\mathrm{kW}), S(p, d c p(p), v(p)) \equiv S$

- $\quad P(p, d c p(p), v(p))$ — supplied power in vehicle $p$ on driver's controller position $d c p(p)$ and velocity $v(p)(\mathrm{kW}), P(p, d c p(p), v(p)) \equiv P$

- $\quad F_{A}(p, d c p(p), v(p))$ - traction force in vehicle $p$ with asynchronous traction motor on driver's controller position $d c p(p)$ and velocity $v(p)$

- $\quad \eta_{A}(p, d c p(p), v(p))$ - energy efficiency of motor in vehicle $p$ with asynchronous traction motor on driver's controller position $d c p(p)$ and velocity $v(p)$.

Our calculations assume that the parameters do not depend on the operation mode of the motor, particularly on the saturation of its magnetic system. In this case, the inductance of the magnetizing circuit corresponds to a saturated magnetic system in the nominal mode. The accuracy of calculations can be improved when specifying the equivalent circuit parameters, for example, when using calculations based on the finite element method. The calculations were performed for the velocity range of $1-60 \mathrm{~km} / \mathrm{h} \mathrm{km} / \mathrm{h}$ corresponding to the thrust force at the start and the summed power.

The rotor current frequency where initial tractive force is achieved for each velocity value or the power supplied to electric motors has been defined. The initial value of the rotor current frequency has been assumed as $0.01 \mathrm{~Hz}$ and rises in increments of $0.01 \mathrm{~Hz}$. The dependence of voltage on the frequency is considered proportional $(\mathrm{U} / \mathrm{f}=$ const $)$ until the voltage becomes equal to the maximum voltage of the motor.

The motor operates with the rated flux coupling in the range where the power is supplied according to $U / f=$ const. It is assumed that the voltage of the intermediate circuit of the traction converter for all operation modes of the motor is $600 \mathrm{~V}$. It has been assumed that the losses in the traction converter are proportional to the phase current. Power losses in the electric motor from maximum harmonic voltages and currents are estimated as $0.5 \%$ of the supplied power for all operating modes.

The energy efficiency of the motor with asynchronous traction motor $\eta_{A}(p, d c p(p), v(p))$ is calculated from Equation (2).

$$
\eta_{A}(p, d c p(p), v(p))=\frac{P_{2, A}(p, d c p(p), v(p))}{P_{1, A}(p, d c p(p), v(p))} \cdot 100 \%[\%]
$$

where:

- $\quad P_{2, A}(p, d c p(p), v(p))$-output mechanical power obtained on motor in vehicle $p$ with asynchronous traction motor on driver's controller position $d c p(p)$ and velocity $v(p)$ $(\mathrm{kW})$

- $\quad P_{1, A}(p, d c p(p), v(p))$-active power absorbed by motor in vehicle $p$ with asynchronous traction motor on driver's controller position $d c p(p)$ and velocity $v(p)$ in steady state $(\mathrm{kW})$

The conducted studies show that an asynchronous motor is more efficient than a DC motor. Moreover, one gear ratio of the traction gear is used in the DC motor. Conversely, in the case of an asynchronous motor, multiple gear ratios can be used. Therefore, the method of selecting energy-efficient parameters of an electric asynchronous traction motor for diesel shunting locomotives will be based on the study of the influence of the traction gear ratio on the locomotive power index.

Work on the development of the method should begin with the definition of a series of input data. They can include:

- $\quad$ set of vehicles $P, P=\{p: p \in \mathbb{N}\}$, where: $p$-number of traction vehicle 
- $\quad$ set of gear ratios of the vehicle $p(p \in P)-G R(p), G R(p)=\left\{g r(p): \operatorname{gr}(p) \in \mathbb{R}^{+}\right\}$, where: $g r(p)$-traction gear ratio (for the sake of simplicity, the figures use the notation that $g r(p) \equiv g r$ and $\boldsymbol{G R}(p) \equiv \boldsymbol{G R})$

- $\quad$ set of driver's controller positions of vehicle $p(p \in \boldsymbol{P})-\boldsymbol{D C P}(p), \boldsymbol{D C P}(p)=\{d c p(p)$ : $d c p(p) \in \mathbb{N}$ \}, where: $d c p(p)$-driver's controller positions (for the sake of simplicity, the figures use the notation that $d c p(p) \equiv d c p$ and $\boldsymbol{D C P}(p) \equiv \boldsymbol{D C P})$

- $\quad$ set of analyzed speeds of vehicle $p(p \in \boldsymbol{P})-\boldsymbol{V}(p), \boldsymbol{V}(p)=\left\{v(p): v(p) \in \mathbb{R}^{+}\right\}$, where: $v(p)$-analyzed speed of the vehicle (for the sake of simplicity, the figures use the notation that $v(p) \equiv v$ and $\boldsymbol{V}(p) \equiv \boldsymbol{V})$

The quantity sought in the method indicates the best value of the electric gear ratio $\operatorname{gr}(p)$ of the asynchronous motor installed in a shunting locomotive with the number $p$ $(p \in P)$.

As an indicator for assessing the quality of the solution (objective function), the efficiency value of the asynchronous motor was adopted, which can be installed in the vehicle number $p(p \in \boldsymbol{P})$, at a specific driver's controller position $d c p(p)$, for speed $v(p)$, at different values of traction gear ratios $g r(p)-\eta_{A S}(p, d c p(p), v(p), \operatorname{gr}(p)), \eta_{A S}(p, d c p(p), v(p), g r(p))$ $\in \mathbb{R}^{+}$, which can be written using the Formula (3):

$$
\begin{gathered}
\forall p \in \boldsymbol{P} \forall d c p(p) \in \boldsymbol{D C P}(p) \forall v(p) \in \boldsymbol{V}(p) \forall g r(p) \in \boldsymbol{G R}(p) \\
\eta_{A S}(p, d c p(p), v(p), g r(p)) \rightarrow \max
\end{gathered}
$$

Of course, several constraints on the decision variables should be defined so that the obtained value is best for the problem. The procedure for calculating the energy efficiency of an asynchronous motor is shown in Figure 5.

Then, according to the Formula (3), one should choose the value of the decision variable $g r(p)$, meaning the electric gear ratio of the asynchronous motor that can be installed in a shunting locomotive in such a way that for all $d c p(p)$ the efficiency values are the best. The traction characteristics for the adopted parameters should be plotted in the next step. 


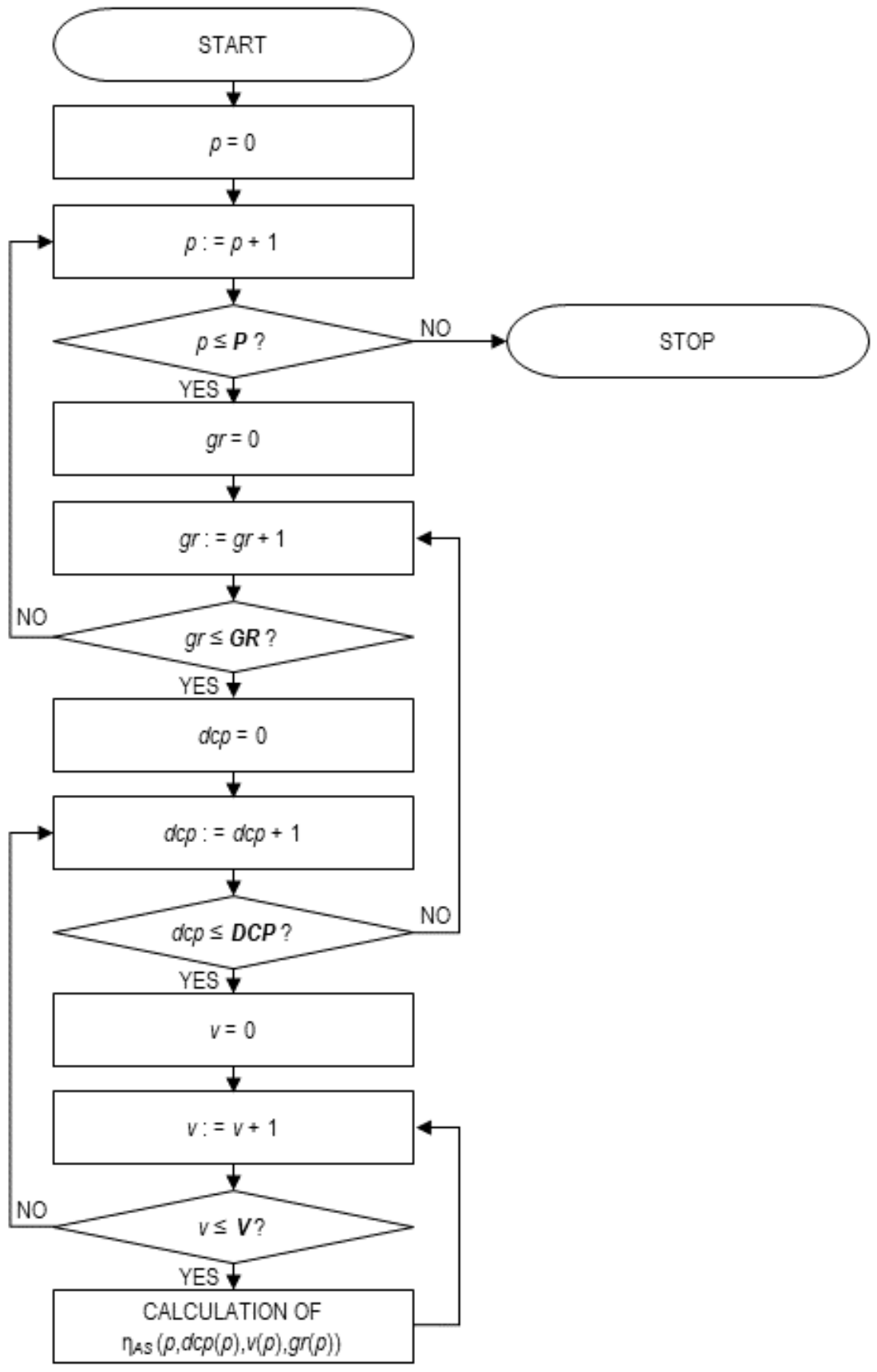

Figure 5. Procedure for calculating the energy efficiency of an asynchronous motor. Source: own work.

4. Application of the Method of Selecting Parameters of an Asynchronous Motor on Accurate Data-A Case Study on the Example of Shunting Locomotive Series ChME3 (ЧMЭ3, С̌ME3, С̌KD S200)

\subsection{General Assumptions}

In our example, we will assess the power efficiency of the above-indicated traction electric drives for the ChME3 locomotive. The fundamental technical parameters of locomotives and electric motors are shown in Tables 1 and 2 [21]. 
Table 1. Technical parameters of ChME3 locomotive.

\begin{tabular}{ccc}
\hline Technical Parameter & Unit of Measurement & Value \\
\hline Axial configuration & & Co-Co \\
Power & $\mathrm{kW}$ & 957 \\
Traction force under long-term mode & $\mathrm{kN}$ & 230 \\
Start traction force & $\mathrm{kN}$ & 369 \\
Construction speed & $\mathrm{km} / \mathrm{h}$ & 95 \\
Mass & $\mathrm{t}$ & 120 \\
Wheel diameter & $\mathrm{m}$ & 1.05 \\
The gear ratio of the traction gearbox & & 5.067 \\
\hline
\end{tabular}

Table 2. Technical parameters of TE-006 electric motors in the operation modes of ChME3 locomotives.

\begin{tabular}{ccc}
\hline Technical Parameter & Unit of Measurement & Value \\
\hline Power on the shaft under long-term mode & $\mathrm{kW}$ & 123 \\
Current under long-term mode & $\mathrm{A}$ & 750 \\
Max. voltage & $\mathrm{V}$ & 283 \\
Velocity under long-term mode & $\mathrm{rpm}$ & 295 \\
Torque under long-term mode & $\mathrm{Nm}$ & 3983 \\
Max. velocity & $\mathrm{rpm}$ & 2420 \\
Efficiency factor under long-term current & $\%$ & 83.2 \\
\hline
\end{tabular}

The power at the terminals of the ChME3 locomotive traction generator and the initial tractive force depending on the driver's controller position are referred to in Table 3 [22].

Table 3. Power and start tractive force.

\begin{tabular}{ccc}
\hline $\begin{array}{c}\text { Position of the Driver's } \\
\text { Controller }\end{array}$ & $\begin{array}{c}\text { Power Supplied to Traction } \\
\text { Electric Motors, } \mathbf{k W}\end{array}$ & Initial Traction Force, kN \\
\hline 1 & 28 & 90 \\
2 & 98 & 180 \\
3 & 220 & 246 \\
4 & 310 & 312 \\
5 & 410 & 360 \\
6 & 530 & 360 \\
7 & 720 & 360 \\
8 & 880 & 360 \\
\hline
\end{tabular}

In the literature, we can find many different techniques for calculating the efficiency of in-service electric motors [23-25]. The techniques used in our studies are described below.

\subsection{Calculation of the Traction Characteristics of a Locomotive with DC Electric Motors}

As mentioned in Section 3, the first step of the method is followed to determine the traction characteristics of the locomotive with DC electric motors. The initial data required for calculating the characteristics were determined according to the technical documentation for the ChME3 diesel locomotive (for example, [13,16], repair manual and others). Figure 6 shows the calculated traction characteristics of the ChME3 locomotive on the driver's controller positions (DCP). 


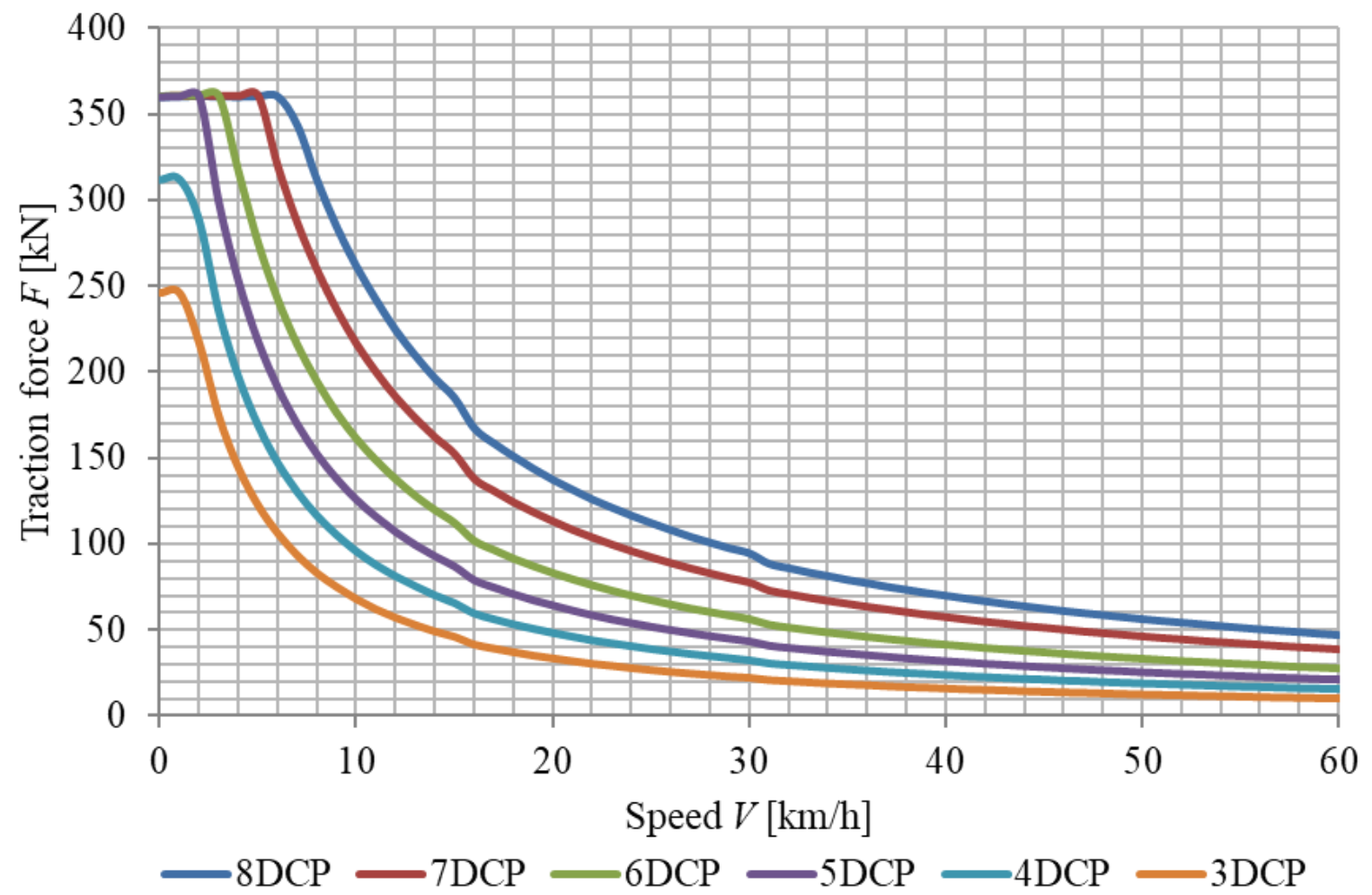

Figure 6. Estimated traction characteristics of the ChME3 locomotive (3DCP-8DCP-position number of the driver's controller from 1 to 8 respectively). Source: own work.

Figure 7 shows the dependence of the velocity efficiency in the range of $1-60 \mathrm{~km} / \mathrm{h}$ for different positions of the driver's controller.

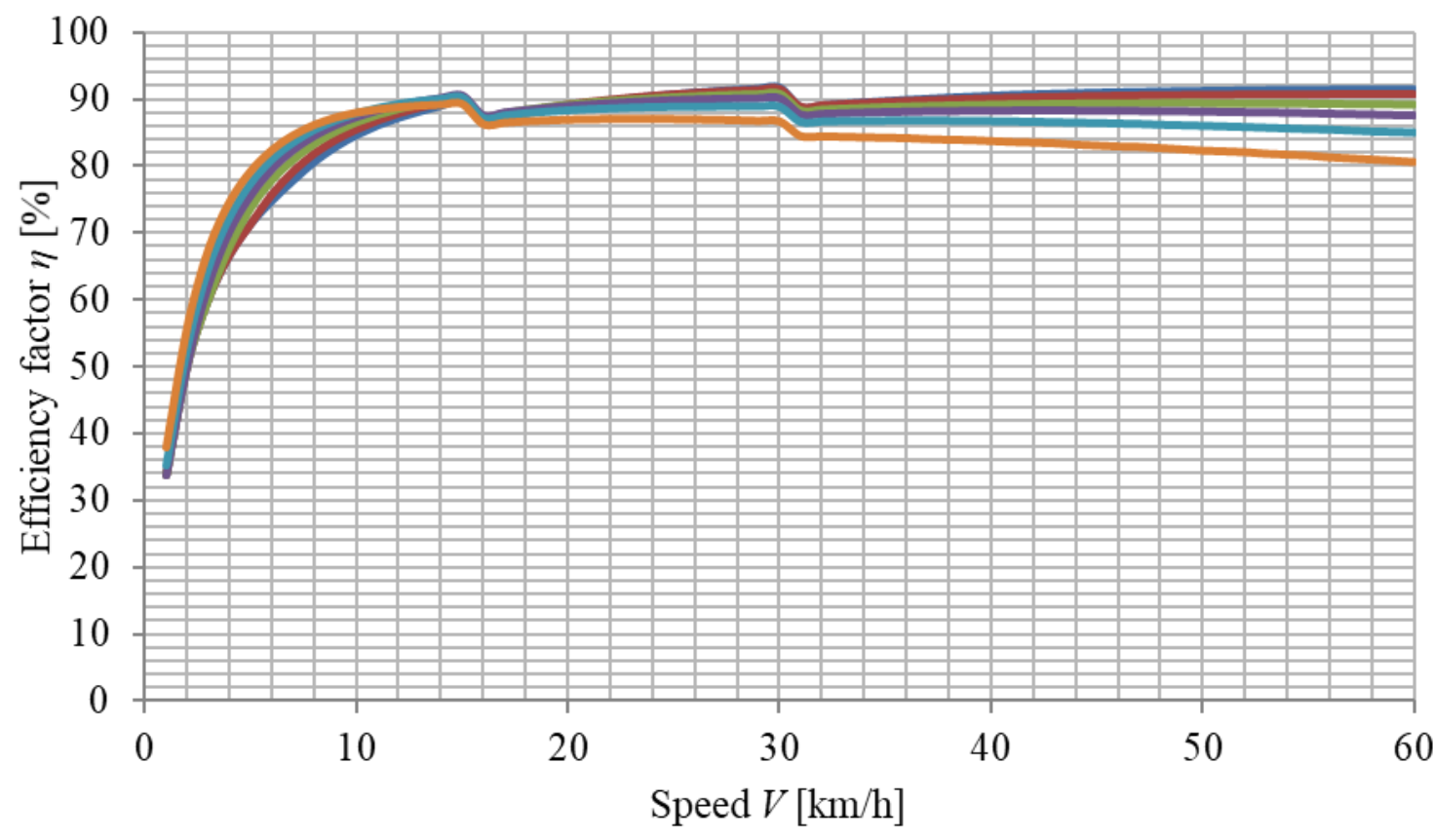

$-8 \mathrm{DCP}-7 \mathrm{DCP}=6 \mathrm{DCP}-5 \mathrm{DCP}=4 \mathrm{DCP}=3 \mathrm{DCP}$

Figure 7. Dependence of efficiency on velocity for different positions of the driver's controller (3DCP-8DCP-position number of the driver's controller from 3 to 8, respectively). Source: own work. 
From Figure 7, it becomes clear that the efficiency of long-term operation (at velocities higher than $11 \mathrm{~km} / \mathrm{h}$ ) is $80-92 \%$ (most cases over $85 \%$ ).

\subsection{Calculation of the Traction Characteristics of the ChME3 Locomotive with Traction Asynchronous Electric Motors}

The second step of the method is to determine the traction characteristics of the locomotive with traction asynchronous electric motors (see Section 3 of the article). Estimation of power factors of the traction asynchronous electric drive for the ChME3 locomotive was carried out using the example of an asynchronous traction motor with nominal parameters, shown in Table 4. The authors developed the electric motor upgrade by the technique of calculation of traction asynchronous electric motor. The installation and connection dimensions of the machined traction asynchronous motor correspond to the dimensions of the TE006 motor.

Table 4. Rated technical parameters of the traction induction motor.

\begin{tabular}{ccc}
\hline Parameter Nomenclature & Unit of Measurement & Value \\
\hline Power & $\mathrm{kW}$ & 120 \\
Linear voltage & $\mathrm{V}$ & 215 \\
Max. linear voltage & $\mathrm{V}$ & 400 \\
Phase current & $\mathrm{A}$ & 395 \\
Rotation velocity, & $\mathrm{rpm}$ & 156 \\
Max. Rotation velocity & $\mathrm{rpm}$ & 2500 \\
Torque & $\mathrm{Nm}$ & 7340 \\
Max. torque & $\mathrm{Nm}$ & 8740 \\
Frequency & $\mathrm{Hz}$ & 8.3 \\
Max. frequency & $\mathrm{Hz}$ & 97.9 \\
Number of poles & - & 6 \\
Number of phases & - & 3 \\
Efficiency factor, & $\%$ & 85.0 \\
Power factor & - & 0.96 \\
Slip & $\%$ & 5.8 \\
Cooling method & & 0.35 \\
Cooling air consumption & $\mathrm{m} / \mathrm{s}$ & 2200 \\
Mass & $\mathrm{kg}$ & 0.48 \\
Length of the stator lamination & $\mathrm{m}$ & 0.68 \\
\hline
\end{tabular}

The parameters of the equivalent circuit of the induction motor are shown in Table 5.

Table 5. Parameters of the equivalent circuit of asynchronous electric motor.

\begin{tabular}{ccc}
\hline Parameter Nomenclature & Unit of Measurement & Value \\
\hline Resistance of stator phase at $20^{\circ} \mathrm{C}$ & $\Omega$ & 0.0177 \\
Reduced resistance of rotor at $20^{\circ} \mathrm{C}$ & $\Omega$ & 0.01255 \\
Stator leakage inductance & $\mathrm{mH}$ & 0.439 \\
Rotor reduced leakage inductance & $\mathrm{mH}$ & 0.372 \\
Magnetization inductance & $\mathrm{mH}$ & 15.7 \\
\hline
\end{tabular}

The equivalent circuit parameters referred to in Table 5 are calculated for the rated mode of operation of the electric motor $[17,25]$. The procedure is based on the equivalent circuit of an induction motor. This technique has been tested in calculating the characteristics of an induction motor for various purposes and ensures good agreement between the calculated and experimental data [17]. The calculation is carried out for the fundamental harmonic currents, voltages, and flux linkages. For this article, we consider the accuracy of the results obtained in the calculations according to the mentioned method as sufficient. The increase of consumption when powered from non-sinusoidal voltage requires additional research. 
Figure 8 shows the traction characteristics of the ChME3 locomotive with asynchronous traction drive, and Figure 9 shows the dependence of the traction drive's efficiency on the speed.

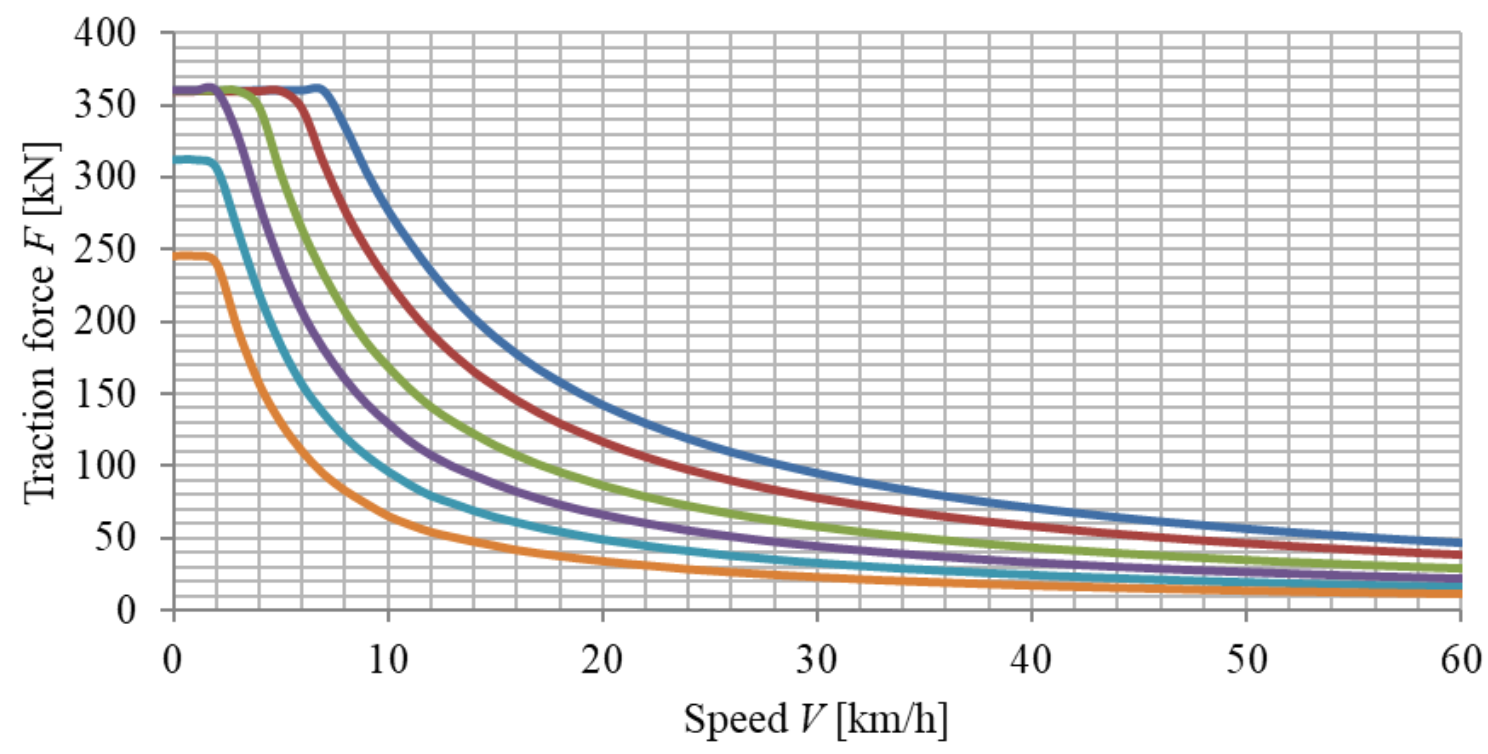

$=8 \mathrm{DCP}=7 \mathrm{DCP}=6 \mathrm{DCP}=5 \mathrm{DCP}=4 \mathrm{DCP}=3 \mathrm{DCP}$

Figure 8. Estimated traction characteristics of the ChME3 locomotive by traction asynchronous electric motors (3DCP-8DCP-position number of the driver's controller from 3 to 8 respectively). Source: own work.

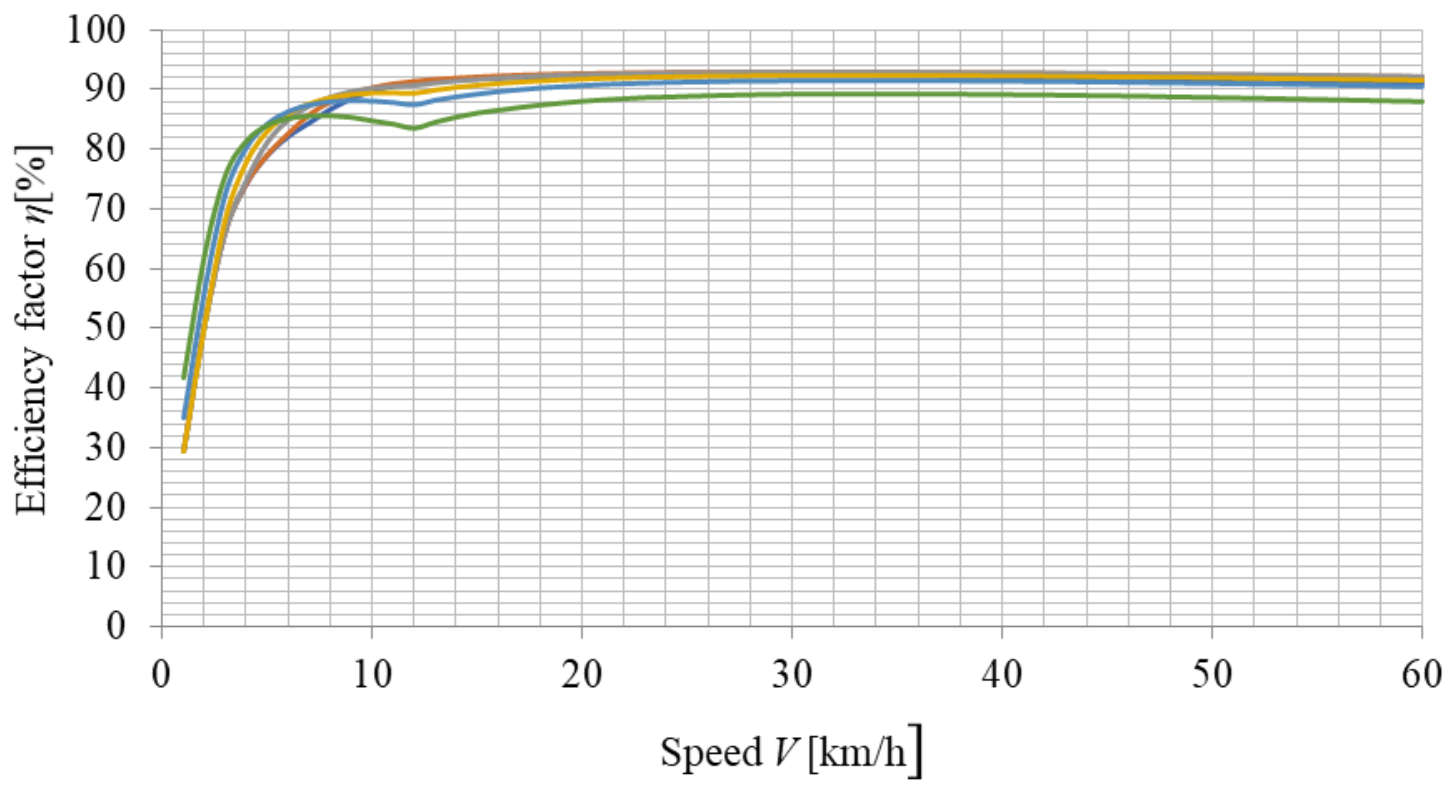

$-8 \mathrm{DCP}-7 \mathrm{DCP}-6 \mathrm{DCP}-5 \mathrm{DCP}-4 \mathrm{DCP}-3 \mathrm{DCP}$

Figure 9. Dependence of efficiency on speed for different positions of the driver's controller (diesel ChME3 locomotive by traction asynchronous electric motors) (3DCP-8DCP are position numbers of the driver's controller from 3 to 8 , respectively). Source: own work. 
From Figure 9, it becomes clear that the efficiency under long-term operation (at speeds greater than $11 \mathrm{~km} / \mathrm{h}$ ) is $86-92 \%$ (as a rule higher than $90 \%$ ).

\subsection{Research of the Ways of the Traction Asynchronous Electric Drive Improvement of the} ChME3 Locomotive

The third step of the developed method is the study of the influence of the traction gear ratio on the locomotive power index (see Section 3 of the article). The above calculations of the traction and energy characteristics of the ChME3 locomotive with DC motors and asynchronous electric drive clearly show a higher efficiency under all modes of the locomotive operation. The calculations were carried out using a serial gearbox with a gear ratio of 5.067. However, the asynchronous motors allow traction gearboxes with larger gear ratios, increasing the traction drive's efficiency [22].

Let us consider the impact of the traction gearbox's gear ratio on the locomotive's power indicators. The efficiency calculation is carried out for the same traction motor with the parameters indicated in Tables 4 and 5 but with different traction gearboxes (with different gear ratios). Optimization of the wheel-motor unit is not considered in this article.

Table 6 shows the numerical values of efficiency within the speed range of $5-25 \mathrm{~km} / \mathrm{h}$ for 3-8DCP. The tabulated values were calculated for the traction induction motor and gearbox with a gear ratio of 6.0 and 7.0.

Table 6. The efficiency of the locomotive traction electric drive.

\begin{tabular}{|c|c|c|c|c|c|}
\hline DCP Number & $\begin{array}{l}\text { Speed, } \\
\text { km/h. }\end{array}$ & $\begin{array}{c}\text { TE006 DC } \\
\text { Motor } \\
\text { with Serial Gearbox } \\
\text { (Gear Ratio 5.067) }\end{array}$ & $\begin{array}{c}\text { Induction } \\
\text { Motor } \\
\text { with Serial Gearbox } \\
\text { (Gear Ratio 5.067) }\end{array}$ & $\begin{array}{c}\text { Induction } \\
\text { Motor } \\
\text { with New Gearbox } \\
\text { (Gear Ratio 6.0) }\end{array}$ & $\begin{array}{c}\text { Induction } \\
\text { Motor } \\
\text { with New Gearbox } \\
\text { (Gear Ratio 7.0) }\end{array}$ \\
\hline \multirow{5}{*}{8} & 5 & 71.3 & 79.0 & 83.7 & 86.7 \\
\hline & 10 & 84.6 & 89.7 & 91.2 & 91.6 \\
\hline & 15 & 89.7 & 91.7 & 92.0 & 92.2 \\
\hline & 20 & 86.6 & 91.9 & 92.1 & 92.3 \\
\hline & 25 & 90.3 & 92.3 & 92.3 & 92.3 \\
\hline \multirow{5}{*}{7} & 5 & 75.7 & 82.6 & 80.0 & 88.4 \\
\hline & 10 & 85.5 & 90.2 & 91.2 & 91.5 \\
\hline & 15 & 90.0 & 92.0 & 92.4 & 92.6 \\
\hline & 20 & 89.2 & 92.5 & 92.7 & 92.8 \\
\hline & 25 & 90.7 & 92.7 & 92.8 & 92.8 \\
\hline \multirow{5}{*}{6} & 5 & 73.8 & 81.2 & 84.7 & 87.1 \\
\hline & 10 & 86.6 & 90.2 & 90.7 & 91.4 \\
\hline & 15 & 87.4 & 91.9 & 92.4 & 92.6 \\
\hline & 20 & 89.2 & 92.5 & 92.7 & 92.9 \\
\hline & 25 & 90.3 & 97.2 & 92.9 & 92.9 \\
\hline \multirow{5}{*}{5} & 5 & 75.6 & 83.2 & 85.9 & 87.6 \\
\hline & 10 & 87.3 & 89.5 & 89.5 & 90.4 \\
\hline & 15 & 90.5 & 90.9 & 91.5 & 92.0 \\
\hline & 20 & 88.9 & 91.9 & 92.2 & 92.4 \\
\hline & 25 & 89.8 & 92.3 & 92.5 & 92.5 \\
\hline \multirow{5}{*}{4} & 5 & 77.4 & 84.2 & 86.2 & 87.3 \\
\hline & 10 & 87.8 & 88.0 & 87.5 & 88.6 \\
\hline & 15 & 90.2 & 89.2 & 90.2 & 90.7 \\
\hline & 20 & 88.3 & 90.6 & 91.1 & 91.4 \\
\hline & 25 & 88.8 & 91.2 & 91.4 & 91.5 \\
\hline \multirow{5}{*}{3} & 5 & 79.3 & 84.0 & 85.2 & 85.6 \\
\hline & 10 & 88.0 & 84.8 & 83.7 & 85.1 \\
\hline & 15 & 89.3 & 86.1 & 87.4 & 88.2 \\
\hline & 20 & 86.9 & 88.0 & 88.8 & 89.2 \\
\hline & 25 & 87.0 & 88.9 & 89.2 & 89.3 \\
\hline
\end{tabular}


Data analysis in Table 6 proves that the electric traction drive based on the asynchronous electric motor in the operation modes of the ChME3 locomotive demonstrates higher efficiency than the serial electric power drive with TE-006 electric motors. The efficiency of the traction asynchronous electric drive attains $92 \%$, exceeding the efficiency of the TE006 serial electric motor by 3-5\%, in the area that corresponds to the long-term operating modes (speed over $11 \mathrm{~km} / \mathrm{h}$ ).

An essential consequence of using asynchronous traction drive is its long operation at speeds below $11 \mathrm{~km} / \mathrm{h}$ (with optimal traction system design). Secondly, it is relatively high energy performance under these modes of operation. For example, at a speed of $5 \mathrm{~km} / \mathrm{h}$, the efficiency of an asynchronous electric drive is about $80-87 \%$ depending on the power, while the efficiency of a DC motor is $70-80 \%$. Under the modes of operation with temporal tractive effort, the efficiency of the asynchronous electric drive exceeds the efficiency of the DC motor by $7-10 \%$. Note that the asynchronous electric drive can operate under such modes for a long time, while for a DC motor, such modes are short.

It also follows from Table 6 that the efficiency value is affected by the gear ratio of the traction gearbox. The increase in the efficiency of the asynchronous traction drive improves the low-speed operation.

Figure 10 shows the traction characteristics of the ChME3 locomotive with the serial electric motors and asynchronous traction electric drive with different gear ratios of the traction gearbox. The traction characteristics of the ChME3 locomotive with traction asynchronous electric drive are higher than the traction characteristics of the locomotive with serial DC motors. This fact is due to the greater efficiency of the electrical asynchronous traction drive.

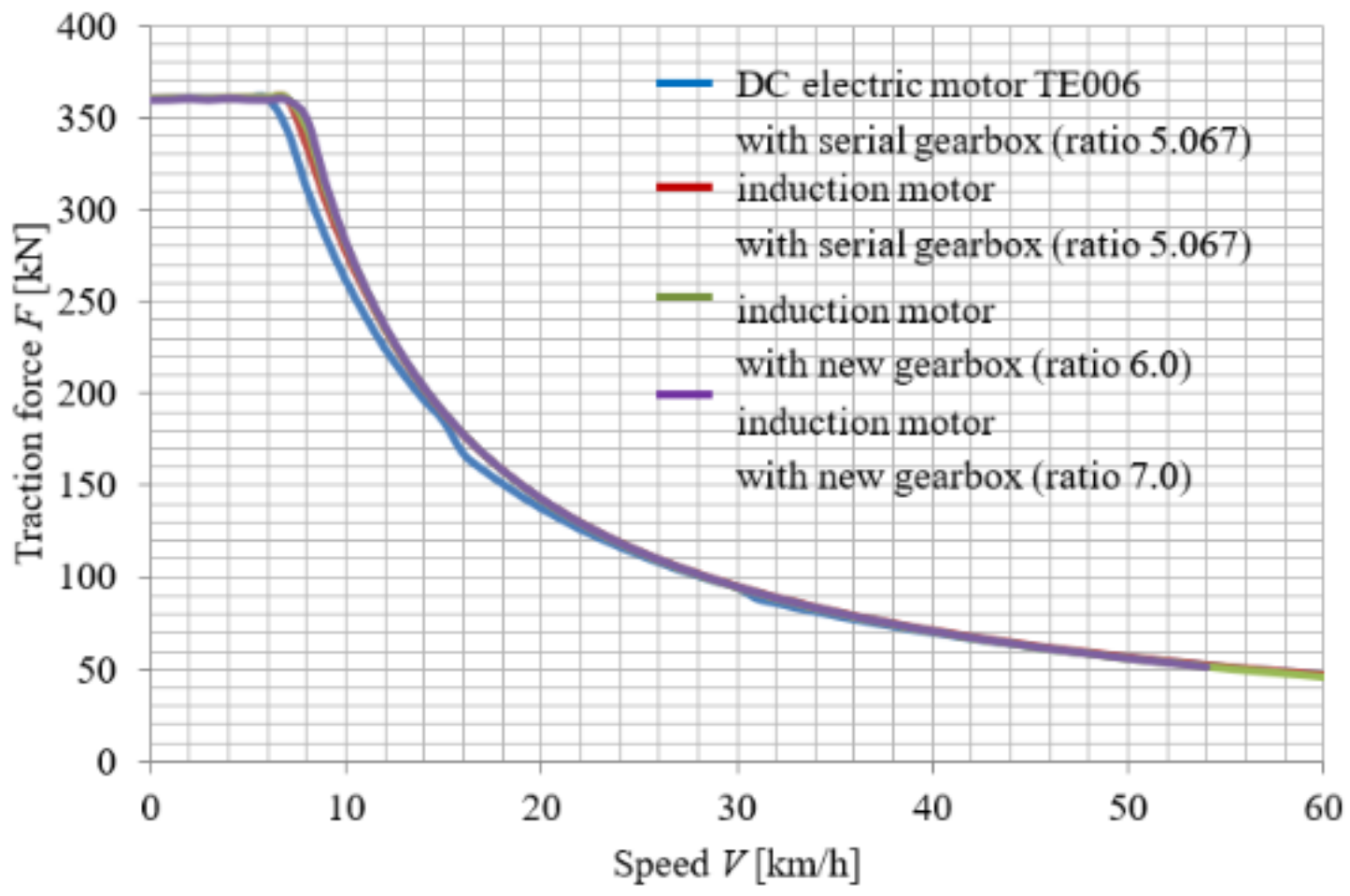

Figure 10. Traction characteristics of the ChME3 locomotive at 8 DCP. Source: own work.

Table 7 shows the values of the phase current of the asynchronous electric motor when starting with the maximum traction force. As can be seen from the table, the phase current value decreases with an increase in the gear ratio. On the one hand, this result decreases losses in the traction inverter and, on the other hand, reduces the cost of the traction converter. Moreover, it should be noted that an increase in the gear ratio also reduces the weight and dimensions of the traction motor. 
Table 7. Values of the phase current of the asynchronous electric motor when starting with the maximum traction force.

\begin{tabular}{ccccc}
\hline Technical Parameter & Unit of Measurement & \multicolumn{3}{c}{ Value } \\
\hline Traction ratio of the gearbox & - & 5.067 & 6.0 & 7.0 \\
\hline $\begin{array}{c}\text { Phase current when starting with } \\
\text { maximum traction force }\end{array}$ & A & 535 & 440 & 365 \\
\hline
\end{tabular}

Thus, traction asynchronous electric motors allow expanding the range of extended modes of operation while ensuring high power efficiency. Considering the research results [26-30], the use of asynchronous electric motors with a traction gearbox with a high gear ratio allows us to create an energy-efficient traction system for a shunting locomotive.

The analysis of the obtained results in Figures 6-10 shows the following. At a continuous speed of the ChME3 locomotive equal to $11 \mathrm{~km} / \mathrm{h}$, the efficiency of the DC motor is about $83 \%$. When using an asynchronous traction drive with an original gearbox, the efficiency of the electric motor is estimated at $88 \%$. With an increase in the gear ratio of traction with asynchronous traction, the efficiency can be increased up to $92 \%$.

When using an asynchronous traction drive, the continuous traction force of the ChME3 locomotive can be increased to $360 \mathrm{kN}$ (versus $230 \mathrm{kN}$ on the original locomotive). In this case, the efficiency of the asynchronous electric motor will be about $87 \%$.

Due to the increase in efficiency when using an asynchronous drive, the traction characteristics of the locomotive slightly change. At a given traction force, the speed of the locomotive increases. If there is no need to change the traction characteristics, the power can be reduced using an asynchronous traction drive.

In the case of an asynchronous traction electric drive, an increase in the gear ratio reduces the maximum currents of the electric motor (in the given example, by 1.4 times). This allows reducing the cost of the traction converter.

In the author's opinion, the obtained conclusions (that with an increase in the gear ratio of the traction gear, the efficiency of the asynchronous electric motor increases and its phase current decreases) are also valid for other considered similar systems.

Therefore, using an asynchronous traction drive on shunting locomotives increases energy efficiency. Since such a drive has several components with different technical parameters, it is necessary to study their influence on the locomotive's performance in future works.

In this article, when varying the gear ratio of the traction gear, the electric motor did not change, which is not entirely rational. A continuation of the work could be a study of the influence of the gear ratio on the characteristics and parameters of the traction motor and electric traction drive as a whole.

It should also be noted that private companies, which are engaged in designing traction asynchronous electric drives for locomotives, do not present the obtained results, so they are inaccessible to a wide range of scientists. Therefore, it is impossible to compare the results obtained in this work with the results of other developers of traction asynchronous electric drives.

\section{Conclusions}

This article aimed to develop a method of selecting energy-efficient parameters of an asynchronous electric traction motor for a diesel shunting locomotive. Its central element is the indication of the best value of the electric gear ratio of the asynchronous motor that can be installed in a shunting locomotive. The selection is made based on an assessment of energy efficiency. Thus, the developed method allows for the indication of energy-efficient parameters of an asynchronous motor during the modernization process, when an internal combustion engine with a DC generator is replaced. The developed method was verified on accurate data, using as an example the modernization of a diesel shunting ChME3 series locomotive. The aim of the article has therefore been achieved. 
During the modernization of the shunting diesel-electric locomotive, it is possible to improve the energy efficiency of the locomotive traction drive by taking the following measures.

1. It has been found that using a traction asynchronous electric drive on a ChME3 locomotive (as an example), its efficiency increases in comparison with DC electric motors by $3-5 \%$ under the long-term operation modes and by $7-10 \%$ during locomotive operation with traction at the adhesion limit. Using a new traction gearbox with a higher gear ratio expands the speed range in which the asynchronous traction drive operates with a high-efficiency factor. Changing the gear ratio from 5.067 to 7.0 increased the efficiency factor by $3-5 \%$. In this case, the phase current decreases by 1.4 times.

2. It is effective to use a traction asynchronous electric drive in the modernization of ChME3 diesel locomotives in case of their use under the modes requiring the implementation of maximum traction forces at low speeds, e.g., for the operation on marshalling humps, cargo removal work on a heavy profile, etc.

3. A further increase in the efficiency of the traction asynchronous electric drive is possible based on the optimal design of the wheel-motor unit and the asynchronous traction electric drive.

Author Contributions: Conceptualization, V.K., P.G. and B.L.; methodology, V.K., P.G., M.G. and B.L.; software, V.K. and L.K.; validation, V.K. and B.L.; formal analysis, E.K.-C. and P.G.; resources, M.G., E.K.-C. and M.O.; data curation, I.R. and L.K.; writing-original draft preparation, I.R., P.G. and L.K.; writing-review and editing, E.K.-C. and M.O.; visualization, I.R.; supervision, E.K.-C. and M.O.; funding acquisition, E.K.-C., P.G. and M.O. All authors have read and agreed to the published version of the manuscript.

Funding: This research was funded by the Warsaw University of Technology.

Institutional Review Board Statement: Not applicable.

Informed Consent Statement: Not applicable.

Data Availability Statement: Not applicable.

Conflicts of Interest: The authors declare no conflict of interest. The funders had no role in the design of the study; in the collection, analysis, or interpretation of the data; in the writing of the manuscript; or in the decision to publish the results.

\section{References}

1. Jacyna, M.; Krześniak, M. Computer Support of Decision-Making for the Planning Movement of Freight Wagons on the Rail Network. In Scientific and Technical Conference Transport Systems Theory and Practice; Springer: Cham, Switzerland, 2018; Volume 21, pp. 225-236.

2. Jacyna, M.; Gołębiowski, P.; Urbaniak, M. Multi-Option Model of Railway Traffic Organization Including the Energy Recuperation; Springer: Cham, Switzerland, 2016. [CrossRef]

3. Urbaniak, M.; Kardas-Cinal, E.; Jacyna, M.; Cinal, K. Optimization of Energetic Train Cooperation. Symmetry 2019, 11, 1175. [CrossRef]

4. Szkoda, M.; Satora, M.; Konieczek, Z. Effectiveness assessment of diesel locomotives operation with the use of mobile maintenance points. Arch. Transp. 2020, 54, 7-19. [CrossRef]

5. Jacyna, M.; Żak, J.; Gołębiowski, P. Models of traffic flow distribution for various scenarios of the development of proecological transport system. Arch. Transp. 2014, 32, 17-28. [CrossRef]

6. Izdebski, M.; Jacyna-Gołda, I.; Gołębiowski, P.; Plandor, J. The Optimization Tool Supporting Supply Chain Management in the Multi-Criteria Approach. Arch. Civ. Eng. 2020, 66, 505-524. [CrossRef]

7. Jacyna, M.; Semenov, I. Models of vehicle service system supply under information uncertainty. Ekspolatacja Niezawodn. Maint. Reliab. 2020, 22, 694-704. [CrossRef]

8. Kukulski, J.; Jacyna, M.; Gołębiowski, P. Finite Element Method in Assessing Strength Properties of a Railway Surface and Its Elements. Symmetry 2019, 11, 1014. [CrossRef]

9. Melnik, R.; Chudzikiewicz, A.; Koziak, S.; Opala, M.; Ján, D. Dynamic properties and wear analysis of a rail vehicle with wheels' self-lubricating coatings. Commun. Sci. Lett. Univ. Zilina 2021, 23, B22-B32. [CrossRef]

10. Jacyna, M.; Szczepański, E.; Izdebski, M.; Jasiński, S.; Maciejewski, M. Characteristics of event recorders in Automatic Train Control systems. Arch. Transp. 2018, 46, 61-70. [CrossRef] 
11. Farnesi, S.; Marchesoni, M.; Passalacqua, M.; Vaccaro, L. Solid-State Transformers in Locomotives Fed through AC Lines: A Review and Future Developments. Energies 2019, 12, 4711. [CrossRef]

12. Yatsko, S.; Sidorenko, A.; Vashchenko, Y.; Liubarskyi, B.; Yeritsyan, B. Method to Improve the Efficiency of the Traction Rolling Stock with Onboard Energy Storage. Int. J. Renew. Energy Res. 2019, 9, 848-858.

13. Skovron, I.Y.; Demchenko, E.B.; Kuzmenko, E.B. Improving the Efficiency of Shunting Work at Stations of Industrial Enterprises/Prospects for the Interaction of Railways and Industrial Enterprises: Abstracts of the 2nd International Scientific-Practical Conference; DNURT: Kostrina, Ukraine, 2013; pp. 85-86.

14. Buriakovskyi, S.; Maslii, A.; Panchenko, V.V.; Pomazan, D.; Denis, I.V. The research of the operation modes of the diesel locomotive CHME3 on the imitation model. Electr. Eng. Electromec. 2018, 2, 59-62. [CrossRef]

15. Lyubarsky, B.G.; Yeritsyan, B.K.; Yakunin, D.I.; Riabov, E.S. Improving the traction and energy characteristics of shunting locomotives. In Proceedings of the International Scientific and Technical Conference "Energy Efficiency in Transport", Kharkiv, Ukraine, 18-20 November 2020; UkrDUZT: Kharkiv, Ukraine, 2020; p. 172.

16. Yeritsyan, B.H.; Yakunin, D.I.; Riabov, I.S. Improving the traction and energy characteristics of shunting locomotives/International scientific and practical conference. In Proceedings of the Science, Engineering and Technology: Global Trends Problems and Solutions, Prague, Czech Republic, 25-26 September 2020; Baltija Publishing: Prague, Czech Republic, 2020; p. 208.

17. Kurbasov, A.S.; Sedov, V.I.; Sorin, L.N. Design of traction motors. MTransp. 1987, 1987, 536.

18. Matsuoka, K.; Kondo, M. Energy Saving Technologies for Railway Traction Motors. IEEJ Trans. Electr. Electron. Eng. 2010, 5, 278-284. [CrossRef]

19. Golubenko, A.L.; Novikov, V.M.; Basov, G.G.; Tulup, V.A.; Tasang, E.H. Calculation of traction and energy characteristics of locomotives: Monograph. Vostochnoukr. Nat. Univ. V. Dahl. Lugansk. Knowl. 2011, 2011, 422.

20. Lyubarsky, B.G. The concept of choosing an electric traction drive for a shunting electric locomotive. In Proceedings of the Transport and Technological Complexes. XXI Century: Materials of the V International Scientific and Technical Conference, St. Petersburg, Russia, 2017; pp. 198-204.

21. Notik, Z.H. Diesel Locomotives ChMEZ, ChMEZT, ChMEZE: Driver's Manual, 2nd ed.; Reworked. and ext. Transport; 1996, p. 444 Available online: https://www.pomogala.ru/books_4_teplovoz/notik_chme3_96.html (accessed on 17 December 2021).

22. Grudin, N. Electronic Regulator of Diesel Locomotive ChME3; Textbook. M Marshrut; 2005; p. 79. Available online: http:/ /katalog. kurskonb.ru/fbd/rf/grudin4/1/assets/common/downloads/publication.pdf (accessed on 17 December 2021).

23. Çunkaş, M.; Sağ, T. Efficiency determination of induction motors using multi-objective evolutionary algorithms. Adv. Eng. Softw. 2010, 41, 255-261. [CrossRef]

24. Sertsöz, M.; Fidan, M.; Kurban, M. Efficiency estimation of induction motors at different size with artificial neural networks and linear estimation using catalog values. Anadolu Univ. J. Sci. Technol. Appl. Sci. Eng. 2018, 19, 293-302. [CrossRef]

25. Kopylov, I.P. Proektirovanie Elektricheskikh Mashin: Uchebnik Dlya Bakalavrov, 4th ed.; Reworked. and ext.; Yurayt Publishing House: Moscow, Russia, 2018; p. 767.

26. Falendysh, A.; Kharlamov, P.; Kletska, O.; Volodarets, N. Calculation of the Parameters of Hybrid Shunting Locomotive. Transp. Res. Procedia 2016, 14, 665-671. [CrossRef]

27. Buriakovskyi, S. Substantiation of the Way of Modernization of Shunting Diesel Locomotives/Serhii Buriakovskyi, Artem Maslii and Olga Pasko. Civil Eng. Res. J. 2019, 7, 555714. [CrossRef]

28. Lyubarsky, B.G.; Overyanova, L.V.; Demidov, O.V.; Riabov, I.S. Innovative energy efficient solutions for the wheel-motor unit of shunting locomotives. In Proceedings of the International Scientific and Technical Conference, "Energy Efficiency in Transport", Kharkiv, Ukraine, 18-20 November 2020; p. 172.

29. Kuznetsov, V.; Lyubarskyi, B.; Kardas-Cinal, E.; Yeritsyan, B.; Riabov, I.; Rubanik, I. Recommendations for the selection of parameters for shunting locomotives. Arch. Transp. 2020, 56, 119-133. [CrossRef]

30. Goolak, S.; Gerlici, J.; Tkachenko, V.; Sapronova, S.; Lack, T.; Kravchenko, K. Determination of Parameters of Asynchronous Electric Machines with Asymmetrical Windings of Electric Locomotives. Commun. Sci. Lett. Univ. Zilina 2019, $21,24-31$. [CrossRef] 